\title{
Storverk om kroppen og sjukdommane for sjukepleieutdanninga
}

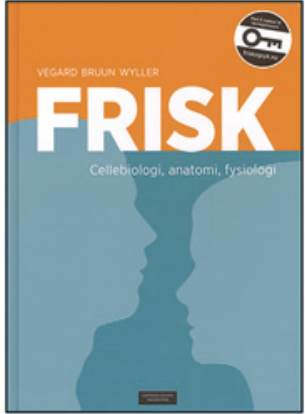

Vegard Bruun Wyller

Frisk

Cellebiologi, anatomi, fysiologi. 3. utg. 712 s, tab, ill. Oslo: Cappelen Damm Akademisk, 2014. Pris NOK 999

ISBN 978-82-02-44497-6

Vegard Bruun Wyller

Syk 1+2

2 bd. Mikrobiologi, patofysiologi, farmakologi, klinisk medisin. 3. utg. 1278 s, tab, ill. Oslo: Cappelen Damm Akademisk, 2014. Pris NOK 1999 ISBN 978-82-02-44499-0

Trebindsverket Frisk og Syk 1+2 dekker pensumkrava i dei naturvitskaplege og medisinske fagområda for bachelorutdanninga i sjukepleiefaget over om lag 2000 sider. Bøkene om den friske og den sjuke kroppen er bygt opp parallelt. I tillegg er det ein omfattande nettressurs med mange oppgåver, pasienthistorier, forslag til utfyllande litteratur og nokre filmar. Som ledd i bokomtalen har forlaget gitt meg tilgang til nettsidene $\mathrm{i}$ ein periode.

Verket er ei vidareføring av seksbindsverket Det friske og Det syke mennesket frå 2005 frå forlaget Akribe. Dette var pedagogisk nyskapande ved at kvart bind utgjorde to parallelle bøker, bunde saman i eit spiralbindsystem slik at kvar bok om det friske mennesket kunne bladast i uavhengig av bindet om det sjuke mennesket. Denne tredje utgåva er i tre tradisjonelle bind, med eitt bind om basalfaga og det friske, og to bind om sjukdomslæra og sjukdommane.

Barnelege og professor Vegard Bruun Wyller står framleis som eineansvarleg for verket, og det er både ei bragd og sjølvsagt ei stor utfordring å ta eit formelt eineansvar for eit så svært prosjekt. Sjølv om forfattar og forlag har brukt fagkonsulentar, er det til slutt signaturen til hovudredaktøren som gjeld. Som for dei førre utgåvene, er eg begeistra for form og uttrykk, og litt kritisk til innhaldet her og der.

Frisk integrerer cellebiologi, anatomi og fysiologi på ein god måte. Det er omfattande bruk av figurar og tabellar som utfyller teksten. Stoffmengda er omfattande. Eg kjenner ikkje pensumkrava for basalfag i sjukepleieutdanninga, men mange stader synes eg detaljgraden og til dels ordbruken er meir avansert enn det eg ville forvente. Spesielt gjeld dette ein del biokjemiske prosessar, til dømes blir svingingar i ionediffusjonen omtalt som kjent omgrep i omtalen av sinusknuten, mens ordet ionediffusjon ikkje er eit stikkord. Det som fungerer fint, er dei mange kliniske eksempla og tilvisingar til sjukdomsdelen av verket.

Sjukdomsdelen startar grunnleggande med 250 sider om sjukdomsprosessar, ulike undersøkingar (klinisk, biokjemisk, røntgen osv.) og behandlingsprinsipp, før det er ein systematisk gjennomgang av organsystema. Vi får i første del også ein forsiktig introduksjon til usikkerhet ved medisinske undersøkingar med omgrepa sensitivitet og spesifisitet, utan at dei blir eksemplifisert i særleg grad i den kliniske delen.
Sjukdommane er samla i tradisjonelle sjukdomskapittel, slik vi kjenner det frå andre lærebøker, og er svært omfattande. Det er nok ein viss sentrering mot det indremedisinske, men ikkje slik at ortopedi eller augesjukdommar vert behandla med harelabb. Tvert imot vil studentane finne litt om det aller meste, også relativt sjeldne sjukdommar. Benign prostatahyperplasi er av ein eller annan grunn plassert i kapitlet om urinvegssjukdommar og ikkje i kapitlet om prostatasjukdommar.

Eg har ikkje funne alvorlege feil i nokre tilfeldige omtalar eg har sjekka i detalj. Nokre småfeil her og der når det gjeld oppdatert kunnskap om årsaker, behandling og bruk av legemiddel har eg funne. Det bør ikkje stå i ei overskrift at stressinkontinens hos kvinner som oftast skuldast lågt østrogennivå. Ein bruker ikkje FSH og LH til å slå fast om pasienten er i klimakteriet eller ikkje. Det er også vanskeleg å unngå raske utdateringar når ein bruker mange kommersielle legemiddelnamn i parentes bak det generiske, og det favoriserer også originalpreparatet lenge etter at patentet er gått ut.

Verket gir eit imponerande visuelt inntrykk, er forseggjort og nyttar avanserte grafiske verkemiddel i form av fargar, rammer, teikningar og tabellar. Biletredaktør og medisinsk illustratør har vore Kari C. Toverud, og teikningane hennar og den gjennomførte bruken av andre illustrasjonar gjev boka eit delikat preg. Figurane er svært gode, og mange gjev eit tredimensjonalt uttrykk. I og over dei anatomiske teikningane er det lagt inn grafiske element som er svært illustrative. Eg har ikkje funne alvorlege feil i dei teikningane og illustrasjonane eg har sjekka.

Nettressursane er eg svært imponert over. Både omfanget, variasjonen og dei tekniske løysingane er noko av det beste eg har erfart, både for norske og utanlandske læreverk. All ære til forfattar og forlag for denne satsinga. Utfordringa er å få tilbodet brukt av studentane. Det står i alle fall ikkje på tilbodet.

Stikkordregister er alltid ei utfordring for så store verk. Det er eige stikkordregister for Frisk og eit samla for Syk 1+2 i siste bind. Registeret er tilfredsstillande i omfang og på dei stikkprøvene eg har gjort. Men å bruke nesten ei side på stikkordet «akutt» i alle former, frå akutt abdomen til akuttfasereaksjon er neppe å tilpasse seg korleis lesaren vil leite etter til dømes (akutt) keisarsnitt.

Eg er glad for å ha bøkene i hylla og skal skifte dei gamle ut med siste utgåve. Sjukepleiestudentane kan ønskjast til lukke med eit norskprodusert læreverk dei vil få mykje nytte av!

\section{Steinar Hunskår}

Professor, Faggruppe for allmennmedisin

Institutt for global helse og samfunnsmedisin

Universitetet i Bergen

Oppgitte interessekonflikter: Anmelder er redaktør av læreboka Allmennmedisin på Gyldendal akademisk. Dette forlaget har utgitt konkurrerande læreverk for sjukepleieutdanninga. 